\title{
ANALISIS KESULITAN SISWA DALAM MENYELESAIKAN SOAL HIGHER ORDER THINKING SKILL (HOTS) SISTEM PERSAMAAN LINEAR DUA VARIABEL
}

\section{ANALYSIS OF STUDENT DIFFICULTIES IN COMPLETING HIGHER ORDER THINKING SKILL (HOTS) PROBLEM OF TWO VARIABLES LINEAR EQUATION SYSTEM}

\author{
Arie Purwa Kusuma1)", Syita faith 'Adna') \\ 1) STIKP Kusuma Negara, Jl. Raya Bogor Km. 24 Cijantung, Jakarta \\ *arie_pk@stkipkusumanegara.ac.id \\ 2) Universitas Pekalongan, Jl. Sriwijaya No. 3, Pekalongan
}

\begin{abstract}
In the 2013 curriculum, students were required to master HOTS questions. Of course this was a challenge for teachers to create quality learning so that students caould understand and solve HOTS questions well. However, in reality, not a few students had difficulty solving HOTS questions. In this study, the aim of this study was to determine the factors that cause students' difficulties in understanding learning and solving HOTS questions on the SPLDV material, especially on questions of understanding and application. This research was a descriptive qualitative research. The research subjects were VII students of MTs Muawanatul Islamiyyah in the 2019/2020 academic year. The data used in this study are test results, interviews, and documentation. Taking the subject using purposive sampling technique. The research results were obtained. 1) Lack of understanding of the concepts used in calculations, 2) not being able to understand questions in the form of narrative, 3) misrepresenting the questions from the questions, 4) lack of practice in solving problems in the two-variable linear equation system.
\end{abstract}

Keywords: Difficulty solving problems, understanding questions, HOTS.

\begin{abstract}
ABSTRAK
Pada kurikulum 2013, siswa dituntut untuk menguasai soal-soal HOTS. Tentu saja hal ini menjadi tantangan bagi guru untuk menciptakan pembelajaran yang berkualitas sehingga siswa dapat memahami dan menyelesaikan dengan baik soal-soal HOTS. Namun, kenyataannya, tidak sedikit siswa yang kesulitan dalam menyelesaikan soal-soal HOTS. Pada penelitian ini bertujuan untuk mengetahui faktor-faktor penyebab kesulitan siswa dalam pemahaman belajar serta penyelesaian soal HOTS pada materi SPLDV khususnya pada soal Pemahaman dan Aplikasi. Penelitian ini merupakan penelitian kualitatif deskriptif. Subyek penelitiannya adalah siswa VII MTs Muawanatul Islamiyyah Tahun ajaran 2019/2020. Data yang digunakan dalam penelitian ini adalah hasil tes, wawancara, dan dokumentasi. Pengambilan subjek dengan menggunakan tekhnik purposive sampling. Hasil penelitian diperoleh. 1) Kurangnya pemahaman konsep yang digunakan dalam perhitungan, 2) tidak mampu memahami soal berupa narasi, 3) salah mendeskripsikan pertanyaan dari soal, 4) kurangnya berlatih dalam menyelesaikan soal sistem persamaan linier dua variable.
\end{abstract}

Kata kunci: Kesulitan penyelesaian soal, soal pemahaman, HOTS. 


\section{PENDAHULUAN}

Pemerintah selalu berupaya meningkatkan kualitas pendidikan nasional, termasuk kualitas pendidikan Matematika. Mulai dari rekonstruksi kurikulum, penerapan model pembelajaran inovatif melalui berbagai pendekatan, hingga terciptanya media pembelajaran berbasis teknologi informasi. Menurut Ma'rufi, dkk (2020), upaya ini merupakan reaksi yang wajar mengingat kebutuhan belajar siswa dan tuntutan kurikulum juga meningkat.

Dalam pembelajaran Matematika, siswa sering dihadapkan dengan soal pemecahan masalah Matematika. Selama ini pemecahan masalah Matematika yang diberikan kepada siswa berkaitan dengan kemampuan mengaplikasikan rumus, prosedur atau algoritma matematika (Dewantara, Zulkardi \& Darmawijoyo, 2015; Kusaeri \& Aditomo, 2019). Pemecahan masalah Matematika belum mengarahkan dan memotivasi siswa untuk mengasah kemampuan analitis, evaluatif dan kreatifnya. Ketidaktahuan siswa dalam mengerjakan dan menyelesaikan soal jenis HOTS membuat siswa kesulitan untuk menemukan jawaban yang benar atas soal matematika jenis HOTS. Kondisi ini dapat membawa dua kemungkinan konsekuensi. Pertama, siswa dengan tingkat keingintahuan yang tinggi akan menganggap tes matematika tipe HOTS sebagai tantangan. Setelah mereka dapat memecahkan masalah matematika HOTS, mereka akan bersemangat dan termotivasi untuk menyelesaikan pertanyaan HOTS lainnya. Dalam perspektif ini, pertanyaan HOTS berhasil memicu minat siswa. Kemungkinan lain, siswa yang memiliki minat rendah terhadap matematika mungkin merasa putus asa ketika harus menyelesaikan soal matematika HOTS. Mereka akan cenderung memilih pertanyaan matematika yang biasa mereka hadapi. Dengan demikian, mereka tidak terbiasa menyelesaikan soal matematika HOTS (Kamarullah, 2017).

HOTS adalah keterampilan yang lebih dari sekedar mengingat, memahami dan mengaplikasikan (Rosnawati, 2005). Pada kurikulum 2013, siswa dituntut untuk menguasai soal-soal HOTS. Tentu saja hal ini menjadi tantangan bagi guru untuk menciptakan pembelajaran yang berkualitas sehingga siswa dapat memahami dan menyelesaikan dengan baik soal-soal HOTS. Sebagai keterampilan kognitif, HOTS sangat dibutuhkan oleh siswa di setiap jenjang pendidikan dan mata kuliah, salah satunya mata kuliah Matematika. HOTS merupakan skill yang harus ada di setiap pelajaran (Sulaiman, Muniyan, Madhvan, Hasan, Rahim, 2017). Penerapan HOTS dalam pembelajaran 
dimaksudkan untuk mengubah persepsi bahwa matematika adalah mata pelajaran yang sulit, dan untuk menarik perhatian peserta didik untuk mempelajari matematika (Abdullah, Mokhtar, Halim, Ali, Tahir, \& Kohar, 2017).

HOTS memiliki peran penting dalam melatih pemikiran logis dan kritis, sebagai serta keterampilan penalaran, yang sangat penting dalam kehidupan sehari-hari. Keterampilan ini juga merupakan bagian dari prestasi akademik (Marshall \& Horton, 2011). Ini menunjukkan bahwa HOTS perlu dimasukkan dalam kurikulum pembelajaran, termasuk pembelajaran Matematika. Sehingga dalam pembelajaran Matematika, penguasaan soal HOTS siswa perlu dievaluasi secara berkala.

Berbagai studi internasional, seperti TIMSS dan PISA dapat dijadikan acuan untuk menentukan Prestasi HOTS siswanya (Budiman \& Jailani, 2014; Jaelani \& Retnawati, 2016; Apino \& Retnawati 2017). Dalam TIMSS 2015, bidang keterampilan matematika Indonesia adalah di peringkat bawah dan keterampilan siswa masih dalam domain 'mengetahui' dan 'menerapkan' atau di keterampilan berpikir tingkat rendah. Dalam domain 'reasoning', keterampilan siswa masih sangat rendah (Mullis, Martin, Foy, \& Hooper, 2016). Sedangkan hasil penilaian PISA tahun 2008, Indonesia memperoleh skor literasi matematika sebesar 378 dengan skor rata-rata OECD 487, dimana Indonesia masih berada pada peringkat 10 di bawah. Hal ini menunjukkan bahwa kemampuan HOTS Indonesia masih rendah sehingga dibutuhkan peningkatan agar bisa bersaing dengan negara lain.

Rendahnya kemampuan HOTS Matematika sebaiknya perlu dievaluasi. Analisis kesulitan siswa dalam mengerjakan soal HOTS sangat diperlukan. Berdasarkan analisis tersebut, guru dapat melakukan perbaikan-perbaikan pembelajaran. Guru seharusnya tidak hanya menuntut siswa benar dalam mengerjakan, tanpa latihan-latihan terstruktur dari guru. Dikutip dari Jurnal Ilmiah Analisis Kesulitan Siswa Dalam Pemahaman Belajar Serta Penyelesaiaan Masalah Ruang Dimensi Tiga (Lamanda Ayuningrum, Arie Purwa Kusuma , Nurina Kurniasari Rahmawati : 2019), definisi kesulitan belajar pertama kali dikemukakan oleh The United States Office of Education (USOE) pada tahun 1977 yang dikenal dengan Public Law (PL) 94 - 142. Definisi ini hampir identik dengan definisi yang dikemukakan oleh The National Advesory Committee on Handicapped Children pada tahun 1967 yang dikutip oleh (Abdurrahman: 2003) menyatakan bahwa kesulitan belajar adalah gangguan dalam satu atau lebih dari proses psikologis dasar yang mencakup 
pemahaman dan penggunaan bahasa ujaran atau tulisan. Gangguan tersebut mungkin menampakkan diri dalam bentuk kesulitan mendengarkan, berpikir, berbicara, membaca, menulis, mengeja, atau berhitung. Definisi lain yang dikemukakan oleh The National Joint Commite for Learning Dissabilites (NJCLD) dalam (Abdurrahman: 2003) menyatakan bahwa kesulitan belajar menunjuk kepada sekelompok kesulitan yang dimanifestasikan dalam bentuk kesulitan nyata dalam kemahiran dan penggunaan kemampuan mendengarkan, bercakap-cakap, membaca, menulis, menalar atau kemampuan dalam bidang studi matematika.

Kesulitan belajar tampil sebagai suatu kondisi ketidakmampuan yang nyata pada orang-orang yang memiliki intelegensi rata-rata hingga superior, yang memiliki sistem sensoris yang cukup dan kesempatan untuk belajar yang cukup pula. Kesulitan belajar dapat berwujud sebagai suatu kekurangan dalam satu atau lebih bidang akademik, baik dalam mata pelajaran yang spesifik seperti membaca, menulis, matematika, dan mengeja, atau dalam keterampilan yang bersifat lebih umum seperti mendengarkan, berbicara, dan berpikir. Tentu saja, siswa yang memiliki kesulitan belajar dapat memperoleh prestasi belajar jauh di bawah potensi yang dimiilikinya.

Banyak penelitian telah dilakukan untuk menyelidiki kesulitan siswa dalam memecahkan soal tes matematika. Jupri dan Drijvers (2016) telah menyelidiki kesulitan siswa dalam memecahkan soal aljabar kata (cerita) dan hasilnya menunjukkan bahwa siswa mengalami kesulitan dalam merumuskan model matematika yang ditunjukkan dengan kesalahan dalam persamaan matematika, skema atau diagram. Phonapichat, Wongwanich, dan Sujiva (2014) telah mengidentifikasi siswa kesulitan dalam memecahkan masalah matematika yaitu kesulitan memahami kata kunci masalah, menemukan asumsi dan informasi kunci dalam masalah, menebak-nebak ketika siswa gagal memahami masalah, ketidaksabaran dan keengganan untuk membaca masalah secara menyeluruh, dan siswa tidak menyukai masalah kata panjang. Alhassora, Abu, dan Abdullah (2017) menemukan bahwa kesulitan dalam menyelesaikan soal HOTS disebabkan karena siswa belum terbiasa membaca masalah kata panjang. Hasil penelitian yang dilakukan oleh Prakitipong dan Nakamura (2006) menunjukkan jenis kesalahan siswa yaitu kesalahan pemahaman dalam memecahkan pertanyaan terstruktur dan kesalahan transformasi dalam menyelesaikan pertanyaan pilihan ganda. Sedangkan 
Abdullah dkk. (2015) menemukan bahwa kesalahan siswa terdiri dari pengkodean, keterampilan proses, transformasi, dan pemahaman.

Para guru umumnya memandang semua siswa yang memperoleh prestasi belajar rendah disebut siswa berkesulitan belajar. Secara garis besar kesulitan belajar dapat diklasifikasikan dalam kesulitan belajar yang berhubungan dengan perkembangan dan kesulitan belajar akademik (Abdurrahman: 2003). Kesulitan belajar akademik menunjuk pada adanya kegagalan - kegagalan pencapaian prestasi akademik yang sesuai dengan kapasitas yang diharapkan. Kegagalan-kegagalan tersebut mencakup penguasaan keterampilan dalam membaca, menulis, dan/atau matematika. Kesulitan belajar akademik dapat diketahui oleh guru atau orang tua ketika anak gagal menampilkan salah satu atau beberapa kemampuan akademik.

Materi Sistem Persamaan Linier Dua Variabel (SPLDV) merupakan salah satu materi dari matematika yang diajarkan di Sekolah Menengah Pertama (SMP) kelas VIII semester ganjil. Materi SPLDV di MTs ini dapat dikatakan sebagai materi penghantar untuk mempelajari materi Sistem Persamaan Linier (SPL) lebih lanjut di tingkat Sekolah Menengah Atas (SMA). Selain itu, materi yang berkaitan dengan SPL ini banyak ditemukan dalam kejadian sehari-hari yang dialami oleh siswa sendiri. Berdasarkan hasil wawancara dengan beberapa siswa di MTs Muawanatul Islamiyyah, mereka mengatakan bahwa matematika memang merupakan salah satu mata pelajaran yang sulit dipelajari dan mereka masih mengalami kesulitan dalam memecahkan masalah matematika yang berkaitan dengan penerapan sistem persamaan linier dalam kehidupan sehari-hari.

Selanjutnya, penelitian ini juga di latarbelakangi oleh rendahnya hasil belajar yang diraih siswa pada mata pelajaran matematika kelas VIII MTs Muawanatul Islamiyyah. Sebagian besar siswa mengalami kesulitan terlihat ketika proses belajar mengajar. Hal ini juga didukung dengan hasil belajar siswa yang kebanyakan tidak tuntas atau di bawah KKM 75. Berdasarkan uraian latar belakang masalah di atas, peneliti tertarik untuk menganalisis kesulitan siswa dalam menyelesaikan soal Higher Order Thinking Skill (HOTS) sistem persamaan linear dua variabel.

\section{METODOLOGI}

Penelitian ini menggunakan metode penelitian kualitatif deskriptif. Penelitian deskriptif berisi tentang data-data yang dikumpulkan dan dijelaskan dalam bentuk kata- 
kata. Penelitian deskriptif ini bertujuan untuk menggambarkan kesulitan siswa dalam mengerjakan soal HOTS materi SPLDV. Pengambilan subjek pada penelitian ini adalah menggunakan teknik purposive sampling. Subjek penelitian ini adalah mahasiswa siswa kelas VII MTs Muawanatul Islamiyyah sebanyak 18 siswa,

Teknik pengumpulan data yang digunakan dalam penelitian ini adalah tes, wawancara, dan dokumentasi. Tes digunakan untuk mengukur kemampuan siswa dalam menjawab soal HOTS. Wawancara digunakan untuk mendapatkan data alasan kesalahan siswa dalam menjawab soal. Sedangkan dokumentasi digunakan untuk mengumpulkan hasil pekerjaan siswa.

Data dianalisis secara deskriptif. Penelitian ini dianalisis melalui tiga tahapan sesuai dengan Miles dan Huberman yaitu reduksi data, penyajian data dan penarikan kesimpulan. Siswa diberikan soal SPLDV kemudian dipilih subjek sesuai fokus penelitian ini yaitu menganalisis kesulitan siswa dalam menyelesaikan soal higher order thinking skill (HOTS) sistem persamaan linear dua variabel.

Dimensi proses berpikir dalam Taksonomi Bloom sebagaimana yang telah disempurnakan oleh Anderson \& Krathwohl (2001), terdiri atas kemampuan: mengetahui (knowing-C1), memahami (understanding-C2), menerapkan (aplying-C3), menganalisis (analyzing-C4), mengevaluasi (evaluating-C5), dan mengkreasi (creating-C6). Soal-soal HOTS pada umumnya mengukur kemampuan pada ranah menganalisis (analyzing-C4), mengevaluasi (evaluating-C5), dan mengkreasi (creating-C6) (Widana, 2017). Dalam hal ini, indikator soal HOTS yang dibahas yaitu hanya pada level menganalisis (C4) dan meng-evaluasi (C5).

\section{PEMBAHASAN}

Penelitian ini dilakukan dengan memberikan 5 butir soal HOTS tentang materi sistem persamaan liner dua variable kepada siswa untuk memperoleh hasil kerja siswa. Dalam mengerjakan soal siswa diberikan waktu selama 30 menit tanpa adanya penambahan waktu.Setelah siswa selesai mengerjakan soal selanjutnya dilakukan wawancara untuk mengetahui letak kesulitan yang dialami oleh siswa dalam mengerjakan soal. Berikut ini salah satu contoh hasil kerja dan wawancara dengan siswa.

Soal: 
Andi, Budi, dan Candra bermain game Android. Satu kali permainan, seseorang maksimal mencoba hingga 15 kali. Poin yang diperoleh berdasarkan banyaknya kalah dan menang hingga 15 kali percobaan. Andi sudah bermain sebanyak 11 kali, sedangkan Budi baru 5 kali. Andi tercatat kalah sebanyak 4 kali dan menang sebanyak 7 kali. Sedangkan Budi kalah sebanyak 3 kali dan menang sebanyak 2 kali. Tentu saja poin akan bertambah apabila menang, dan berkurang apabila kalah. Berapakah poin yang diperoleh Candra apabila dari 5 kali percobaan mengalami kalah sebanyak 2 kali dan menang sebanyak 3 kali?

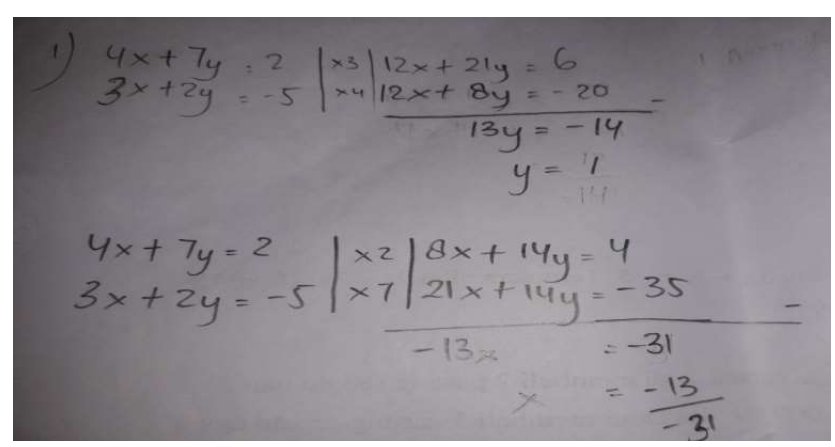

Gambar 1. Hasil kerja siswa soal no. 1

Berdasarkan jawaban pada lembar kerja siswa, siswa tersebut sudah bisa menganalisis unsur yang diketahui. Pada saat analisis nampaknya siswa dapat memisalkan x sebagai variabel kalah dan y sebagai variabel menang, serta poin perolehan. Seolah siswa tidak terkecoh dengan banyaknya perrcobaan yang dilakukan pada soal. Hal yang nampak pada analisis jawaban siswa ini adalah kesalahan siswa mengoperasikan saat melakukan eliminasi. Tentu saja, perlu dikaji informasi lebih dalam terkait hasil pengerjaan siswa. Berikut ini hasil wawancara dengan siswa: (P: peneliti, dan S1: subyek 1)

P : : : itu soal no 1 kenapa tidak diselesaikan?"

S1 : "Bingung di eliminasi dan substistusinya dan saya juga masih bingung di penjumlahan postif dan negatif."

P : "iyakan, kalau substisusi kamu tinggal mengoperasikan hasil dari eliminasi kamu ke persamaan."

S1 : : "Saya belum mengerti cara untuk mensubstitusikan."

P : "Saya tertarik bagaimana kamu bisa memisalkan variabel-variabelnya?"

S1 : "Sepahaman Saya, bisa apa saja, yang satu x yang satu y."

P : "Bagaimana besarnya poin menang dan kalah menurutmu?" 
S1 :"Seharusnya poin menang lebih besar dari poin kalah. Namun, Saya bingung. Hasilnya kog tidak bulat. Makanya saya belum meneruskan pengerjaannya."

Berdasarkan hasil wawancara tersebut, ternyata siswa dapat memahami baik apa maksud dari soal. Siswa dapat memisalkan variabel sesuai informasi soal. Siswa juga paham besarnya poin menang lebih besar dari poin kalah. Akan tetapi siswa tersebut tidak dapat menghitung dengan benar. Siswa belum tepat dalam mengoperasikan eliminasi dan belum bisa melakukan substitusi hasil eliminasi ke soal.

Soal 3:

Suatu persegi panjang, panjangnya $5 \mathrm{~cm}$ lebih panjang dari lebarnya. Jika keliling persegi panjang $38 \mathrm{~cm}$ dan lebar x cm. maka model matematikanya adalah....

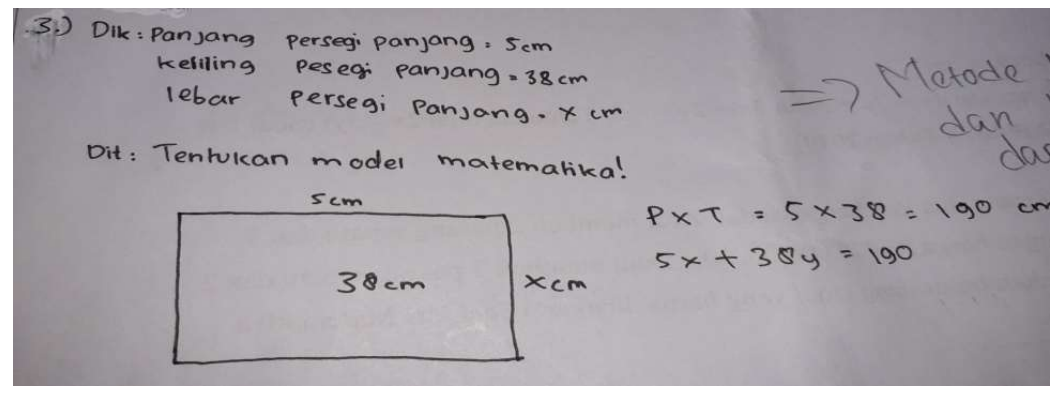

Gambar 2. Hasil kerja siswa no.3

P : nomor 3 kok tidak diselesaikan?"

S2 : : saya belum mengerti bu tentang model matematika."

P : : itu yang no 1 bentuk model matematika atau bukan?"

S2 :" Oh iya itu model matematika. Tadi saya lupa apa yang dimaksud model matematika di soal no 3. Tapi soal yang no 1 lebih mudah dan tinggal di eliminasi dan substitusikan saja, nah kalau yang no 3 kan dia soalnya tentang persegi panjang."

P $\quad$ :" Memangnya kenapa? kan konsepnya sama, cuman di soal yang no 3 itu kita cuman disuruh buat model matematikanya, tidak usah di eliminasikan."

S2 : tetap aja beda bu, kalau soal yang no 1 kan pernah dibuat contoh soal dan saya juga sudah sering mengerjakan soal seperti soal no 1, tetapi kalau soal yang no 3 kan belum pernah sama sekali bu. Terlebih ada kata lebih. Saya juga lupa menghitung keliling persegi panjang."

Berdasarkan hasil wawancara dengan siswa subyek 2 (S2) di atas dapat dianalisis bahwa siswa tersebut belum memahami maksud dari soal. Siswa juga tidak mengetahui bagaimana langkah untuk menyelesaikan soal tersebut dikarenakan lupa dengan konsep 
model matematika. Siwa juga lupa bagaimana menentukan keliling persegi panjang. Siswa kurang berlatih dalam mengerjakan soal tentang menentukan model matematika.

Jadi, berdasarkan beberapa hasil kerja siswa dan wawancara dapat disimpulkan faktor-faktor yang menyebabkan siswa kesulitan dalam mengerjakan soal HOTS sistem persamaan linier dua variable yaitu: 1) Kurangnya pemahaman konsep yang digunakan dalam perhitungan, 2) tidak mampu memahami soal berupa narasi, 3) salah mendeskripsikan pertanyaan dari soal, 4) kurangnya berlatih dalam menyelesaikan soal sistem persamaan linier dua variable.

Kesulitan-kesulitan yang ditemukan berdasarkan hasil penelitian ini, menjadi pertimbangan guru dalam mengajar. Guru seharusnya memperhatikan pemahaman siswa terhadap soal. Siswa harus banyak dilatih dalam membaca. Guru juga lebih berupaya dalam mengasah kemampuan berpikir siswa terutama dalam memahami soal dalam bentuk narasi . selain itu, guru seharusnya juga menanamkan konsep perhitungan. Yang lebih utama, guru harus membiasakan latihan soal-soal yang memerlukan kemampuan berpikir agar mampu menyelesaikan soal HOTS. Sebagaimana menurut Slameto (2010:82-83) " kebiasaan belajar juga akan mempengaruhi belajar itu sendiri" kebiasaan belajar dapat mempengaruhi keberhasilan studi adalah kebiasaan belajar yang baik, sedangkan yang membuat individu gagal adalah karena melaksanakan kegiatan belajar yang buruk.

Kesulitan siswa dalam materi SPLDV ini sebaiknya perlu menjadi perhatian khusus bagi guru mengingat materi ini adalah materi dasar Sistem Persamaan Linier. Penelitian ini juga sejalan dengan penelitian yang dilakukan Sari (2020). Menurutnya, dengan mengetahui kesulitan dalam belajar matematika dapat bermanfaat dalam membantu siswa memperbaiki kesalahan dan mengatasi kesulitan yang dihadapi.

\section{SIMPULAN}

Soal HOTS merupakan soal yang memerlukan penalaran tinggi, karena dengan mengerjakan soal HOTS maka kemampuan analisis siswa akan terlatih, karena pada soal HOTS itu memuat taksonomi bloom yang mulai dari tngkatan C4 (menganalisis). Soal HOTS pada SPLDV merupakan materi yang sulit sehingga perlu untuk dilakukan analisis faktor apa yang menyebabkan siswa dalam mengerjakan soal HOTS khususnya dalam materi SPLDV. Faktor yang menyebabkan siswa kesulitan dalam menyelesaikan soal 
HOTS dalam materi sistem persamaan linier yaitu: 1) Kurangnya pemahaman konsep yang digunakan dalam perhitungan, 2) tidak mampu memahami soal berupa narasi, 3) salah mendeskripsikan pertanyaan dari soal, 4) kurangnya berlatih dalam menyelesaikan soal sistem persamaan linier dua variable. Berdasarkan hasil penelitian yang dilakukan, dapat disimpulkan bahwa dalam menyelesaikan soal HOTS sistem persamaan linier adalah kurang memahaminya konsep SPLDV, kurangnya berlatih dalam menyelesaikan soal sistem persamaan linier yang membutuhkan pemahaman dan penalaran tinggi.

\section{DAFTAR PUSTAKA}

Abdullah, A. H., Mokhtar, M., Halim, N. D. A., Ali, D. F., Tahir, L. M., \& Kohar, U. H. A. (2017). Mathematics teachers' level of knowledge and practice on the implementation of higher order thinking skills (HOTS). EURASIA Journal of Mathematics Science and Technology Education, 13 (1), 3-17. doi:10.12973/eurasia.2017.00601a.

Dewantara, A. H., Zulkardi, Z., \& Darmawijoyo, D. (2015). Assessing seventh graders'mathematical literacy in solving pisa-like tasks. Journal on Mathematics Education, 6(2), 117-128.

Kamarullah, K. (2017). Pendidikan matematika di sekolah kita. Al Khawarizmi: Jurnal

Kusaeri, K., \& Aditomo, A. (2019). Pedagogical Beliefs about Critical Thinking among Indonesian Mathematics Pre-service Teachers. International Journal of Instruction, 12(1).

Kusuma, A. P., \& Rahmawati, N. K. (2019). Analisis Kesulitan Siswa dalam Pemahaman Belajar serta Penyelesaian Masalah Ruang Dimensi Tiga. JKPM (Jurnal Kajian Pendidikan Matematika), 5(1), 135-142.

Kusuma, A. P., Rahmawati, N. K., \& Ramadoni, R. (2020). The Application of the Accelerated Learning Cycle, Brain-based Learning Model, and Direct Instruction Model toward Mathematical Reasoning in Terms of Mathematical Communication. Al-Jabar: Jurnal Pendidikan Matematika, 11(1), 21-28.

Laman, E. G. 2019. Analisis kesalahan siswa dalam dalam memecah kan masalah matematika higher order thinking skills (hots) berdasarkan criteria hadar ditinjau dari kemampuan awal siswa kelas XII SMAN 5 Makassar. Skripsi. Fakultas MIPA Universitas Negeri Makassar. 
Marshall, J. C., \& Horton, R. M. (2011). The relationship of teacher-facilitated, inquirybased instruction to student higher-order thinking. School Science and Mathematics, 111 (3), 93-101.

Ma'rufi, Ma'rufi, Muhammad Ilyas, and Rio Fabrika Pasandaran. "Higher order thinking skills (HOTS) first middle school of class viii students in completing the problem of polyhedron." The 7th South East Asia Design Research International Conference (SEADRIC 2019). No. 1470. IOP Conf. Series: Journal of Physics: Conf. Series 1470 (2020) 012073, 2020.

Rahmawati, N. K., \& Hanipah, I. R. (2018). Penerapan Model Pembelajaran Kooperatif Tipe Think Pair Share (TPS) Dan Model Pembelajaran Kooperatif Tipe Student Team Achievement Division (STAD) Terhadap Hasil Belajar Matematika Siswa Pada Materi Garis Singgung Lingkaran. NUMERICAL: Jurnal Matematika dan Pendidikan Matematika, 43-48.

Sari, Dewi Setia Meita, Syita Fatih ‘Adna, Dewi Mardhiyana. 2020. Analisis Kemampuan Pemecahan Masalah Siswa Berdasarkan Teori Wankat Dan Oreovocz. Jurnal Pendidikan Matematika Undiksha, 11 (2), 15-25.

Widana, I. W. (2017). Modul penyusunan soal higher order thinking skill (HOTS). 